\title{
The Metabotropic Glutamate 2/3 Receptor Agonist LY379268 Blocked Nicotine-Induced Increases in Nucleus Accumbens Shell Dopamine only in the Presence of a Nicotine-Associated Context in Rats
}

\author{
Manoranjan S D'Souza', Matthias E Liechti' ${ }^{2}$, Ana M Ramirez-Niño', Ronald Kuczenski' and Athina Markou*,' \\ 'Department of Psychiatry, School of Medicine, University of California San Diego, La Jolla, CA, USA; ${ }^{2}$ Division of Clinical Pharmacology and \\ Toxicology, Department of Biomedicine, University Hospital and University of Basel, Basel, Switzerland
}

\begin{abstract}
The metabotropic glutamate 2/3 (mGlu2/3) receptor agonist LY379268 ([-]-2-oxa-4-aminobicyclo [3.1.0] hexane-4,6-dicarboxylate) attenuates both nicotine self-administration and cue-induced nicotine seeking in rats. In this study, the effects of LY379268 (I mg/kg) or saline pretreatment on nicotine-induced increases in nucleus accumbens (NAcc) shell dopamine were evaluated using in vivo microdialysis under different experimental conditions: (i) nicotine $(0.4 \mathrm{mg} / \mathrm{kg}$, base) was experimenter-administered subcutaneously to nicotine-naïve rats; (ii) nicotine was experimenter-administered either subcutaneously $(0.4 \mathrm{mg} / \mathrm{kg})$ or by a single experimenteradministered infusion $(0.06 \mathrm{mg} / \mathrm{kg}$, base) in rats with a history of nicotine self-administration (nicotine experienced) in the absence of a nicotine-associated context (ie, context and cues associated with nicotine self-administration); (iii) nicotine $(0.06 \mathrm{mg} / \mathrm{kg}$ ) was selfadministered or experimenter-administered in nicotine-experienced rats in the presence of a nicotine-associated context. In salinepretreated nicotine-naive and nicotine-experienced rats, nicotine increased NAcc shell dopamine regardless of the context used for testing. Interestingly, LY379268 pretreatment blocked nicotine-induced increases in NAcc shell dopamine in nicotine-experienced rats only when tested in the presence of a nicotine-associated context. LY379268 did not block nicotine-induced increases in NAcc shell dopamine in nicotine-naïve or -experienced rats tested in the absence of a nicotine-associated context. These intriguing findings suggest that activation of $\mathrm{mGlu2/3}$ receptors negatively modulates the combined effects of nicotine and nicotine-associated contexts/cues on NAcc dopamine. Thus, these data highlight a critical role for $\mathrm{mGlu2/3}$ receptors in context/cue-induced drug-seeking behavior and suggest a neurochemical mechanism by which $\mathrm{mGlu2/3}$ receptor agonists may promote smoking cessation by preventing relapse induced by the combination of nicotine and nicotine-associated contexts and cues.

Neuropsychopharmacology (20 I I) 36, 2 III-2 I24; doi: I0.1038/npp.20 I I.103; published online 8 June 20 I I
\end{abstract}

Keywords: motivation; self-administration; metabotropic glutamate receptor; microdialysis; dopamine

\section{INTRODUCTION}

The reinforcing effects of nicotine, a major psychoactive component of tobacco smoke, are largely responsible for the maintenance of the tobacco smoking habit in human beings (Goldberg and Henningfield, 1988; Stolerman and Jarvis, 1995). The mesolimbic dopaminergic system, originating in the ventral tegmental area (VTA) and projecting to several cortical and limbic nuclei, including the nucleus accumbens (NAcc) shell, is critically involved in the motivational and

*Correspondence: Professor A Markou, Department of Psychiatry, M/C 0603, School of Medicine, University of California San Diego, 9500 Gilman Drive, La Jolla, CA 92093-0603, USA, Tel: + I 858534 I572, Fax: + I 858534 9917, E-mail: amarkou@ucsd.edu Received 18 December 2010; revised 9 May 2011; accepted 10 May 2011 rewarding properties of drugs of abuse (Wise, 1987; Koob and Volkow, 2010), including nicotine (Balfour, 2009; Di Chiara, 2000; Picciotto and Corrigall, 2002; Watkins et al, 2000, but also see Laviolette and van der Kooy, 2004). The activity of mesolimbic dopaminergic neurons is regulated by glutamatergic inputs to the VTA from several cortical and subcortical regions (Overton and Clark, 1997; Taber et al, 1995; Taber and Fibiger, 1995). Nicotine increases glutamatergic transmission by activating excitatory nicotinic receptors located on presynaptic glutamatergic terminals (Fu et al, 2000; Mansvelder and McGehee, 2002; Reid et al, 2000). Blockade of glutamatergic neurotransmission by systemic administration of receptor antagonists that act at postsynaptically located ionotropic or metabotropic glutamate (mGlu) receptors attenuated both nicotine selfadministration (Kenny et al, 2009, 2003; Liechti and Markou, 2007; Palmatier et al, 2008; Paterson and Markou, 2005; 
Paterson et al, 2003) and nicotine-induced increases in NAcc dopamine release (Fu et al, 2000; Kosowski et al, 2004; Schilstrom et al, 1998; Sziraki et al, 2002).

Similarly, activation of predominantly presynaptic metabotropic glutamate $2 / 3(\mathrm{mGlu} 2 / 3)$ receptors results in decreased glutamate transmission (Cartmell and Schoepp, 2000; Xi et al, 2002a) and had the same effects on nicotine self-administration as blockade of postsynaptic glutamate receptors. Specifically, systemic, intra-VTA or intra-NAcc shell administration of the mGlu2/3 receptor agonist LY379268 ([-]-2-oxa-4-aminobicyclo [3.1.0] hexane-4, 6-dicarboxylate) attenuated nicotine self-administration in rats at doses that had no effect on responding for food (Liechti et al, 2007). In addition, systemic LY379268 administration blocked cue-induced reinstatement of both nicotine- and food-seeking behavior in rats (Liechti et al, 2007). Because mGlu2/3 receptor activation negatively regulates glutamatergic neurotransmission (Cartmell and Schoepp, 2000), we hypothesized that LY379268 decreases the reinforcing effects of nicotine by attenuating nicotineinduced increases in NAcc shell dopamine. This hypothesis is supported by the observation that $\mathrm{mGlu} 2 / 3$ receptors are expressed in the NAcc shell (Testa et al, 1998), and these receptors regulate both basal and psychostimulantinduced NAcc dopamine neurotransmission (Greenslade and Mitchell, 2004; Hu et al, 1999; Karasawa et al, 2006; Kim et al, 2005; Manzoni et al, 1997; Uslaner et al, 2009; Xi et al, 2002a, 2010a, b). Furthermore, activation of mGlu2/3 receptors attenuated the dopamine-dependent psychostimulant-induced enhancement of locomotor activity (Kim et al, 2005; Riegel et al, 2003).

This study assessed the effects of systemic administration of the mGlu2/3 receptor agonist LY379268 on nicotineinduced increases in dopamine in the NAcc shell using in vivo microdialysis in rats. First, the effects of LY379268 pretreatment on experimenter-administered subcutaneous nicotine on NAcc shell dopamine was determined in both nicotine-naïe (ie, rats with no history of nicotine exposure) and nicotine-experienced rats (ie, rats with a history of nicotine self-administration) in an environment never associated with nicotine. The effects of LY379268 in nicotineexperienced animals were evaluated because chronic nicotine self-administration results in functional adaptations in $\mathrm{mGlu} 2 / 3$ receptors in cortical and limbic brain sites, including the VTA and NAcc shell (Liechti et al, 2007). Surprisingly, data from these initial experiments indicated that LY379268 did not influence NAcc dopamine increases induced by subcutaneous administration of nicotine. Because differential neurochemical responses have been reported after self- $v s$ experimenter administration of the same drug (Hemby et al, 1997; Lecca et al, 2007), the effects of LY379268 on NAcc shell dopamine after a single self- or experimenter-administered infusion of nicotine in nicotineexperienced rats was assessed. Findings from these experiments indicated the reversal of nicotine-induced increases in NAcc shell dopamine in LY379268-pretreated rats independent of whether the infusion was self- or experimenteradministered. Because these latter positive findings with LY379268 on nicotine-induced increases in NAcc shell dopamine were seen in rats tested in the presence of a context associated with nicotine self-administration (defined as the combination of both context and cues), whereas the initial negative findings involved testing the rats in a context never associated with nicotine administration, we hypothesized that the presence of a nicotine-associated context was critical to the effects of LY379268. To test this hypothesis, a final experiment assessed the effects of LY379268 pretreatment on NAcc shell dopamine after a single experimenter-administered infusion of nicotine in nicotine-experienced rats in a context never associated with nicotine self-administration.

\section{MATERIALS AND METHODS}

\section{Animals}

Male Wistar rats (Charles River, Raleigh, NC) weighing 275-300 g upon arrival at the laboratory were kept on a reverse $12 / 12 \mathrm{~h}$ light/dark cycle. All procedures were in accordance with the guidelines from the National Institutes of Health and the Association for the Assessment and Accreditation of Laboratory Animal Care and were approved by the Institutional Animal Care and Use Committee.

\section{Drugs}

(-)Nicotine hydrogen tartrate (Sigma, St Louis, MO) was dissolved in saline $(0.9 \%)$ and $\mathrm{pH}$ adjusted to $7.4( \pm 0.5)$ with $1 \mathrm{M}$ sodium hydroxide $(\mathrm{NaOH})$. Nicotine doses are reported as base concentrations. LY379268 was custom synthesized as described previously (Monn et al, 1999) by ANAWA (Wangen, Switzerland). LY379268 (1 mg/kg, salt) was dissolved in $0.9 \%$ saline and $\mathrm{pH}$-adjusted to $7.4( \pm 0.5)$ with $1 \mathrm{M} \mathrm{NaOH}$.

\section{Apparati}

Chambers A: Six custom-made in vivo microdialysis chambers $\left(30 \times 30 \times 35 \mathrm{~cm}^{3}\right)$ had Plexiglas walls, a Plexiglas roof, and a metal grid floor and were housed in soundattenuating boxes (Kuczenski and Segal, 1989). No levers or lights (stimulus or house lights) were present in these chambers. One of the walls had an opening for food and water $3 \mathrm{~cm}$ above the grid floor. The chambers were illuminated by a red light located on one of the inner walls of the sound-attenuating boxes. These chambers were used to conduct microdialysis sessions for nicotine-naïve rats and nicotine-experienced rats in a context not associated with nicotine self-administration.

Chambers B: The operant chambers used for nicotine selfadministration and microdialysis sessions in a context associated with nicotine were standard operant chambers $\left(24 \times 30 \times 28 \mathrm{~cm}^{3}\right.$; Med Associates, St Albans, VT $)$ that had two walls and a roof made of Plexiglas, two walls made of metal, and a metal grid floor. One of the metal walls had two metal retractable levers (each $3 \times 1.8 \mathrm{~cm}^{2}$, one active and one inactive) mounted $6.5 \mathrm{~cm}$ above the metal grid floor with a stimulus/cue light located above each lever. A house light was located in the center of the opposite metal wall $1 \mathrm{~cm}$ from the roof of the chamber. These operant chambers were housed in sound-attenuating boxes (Med Associates). 


\section{Surgery}

An intracranial guide cannula (CMA 12; CMA Microdialysis, Stockholm, Sweden) was implanted $2 \mathrm{~mm}$ above the NAcc shell (flat skull coordinates from bregma: anterior/ posterior $1.7 \mathrm{~mm}$, medial/lateral $\pm 0.8 \mathrm{~mm}$, dorsal/ventral $-4.8 \mathrm{~mm}$ from dura; Paxinos and Watson, 1998), using a stereotaxic frame (David Kopf Instruments, Tujunga, CA) under isoflurane (1-3\%) anesthesia. Cannulae and a slotted tether screw were anchored to the skull with four stainlesssteel screws and dental cement. Self-administering rats (Experiments 2 and $3 \mathrm{a}-\mathrm{c}$ ) were also prepared with intravenous catheters in the jugular vein as described previously (Liechti and Markou, 2007) during the same surgical session. Rats were individually housed after surgery and allowed to recover for at least 1 week before the microdialysis session (Experiment 1) was conducted or before initiating the intravenous nicotine self-administration sessions (Experiments 2 and $3 a-c)$.

\section{Microdialysis Probes}

The inlet and outlet of the microdialysis probes (CMA Elite 12; $2 \mathrm{~mm}$ active membrane; molecular weight cutoff, $20000 \mathrm{Da}$; CMA Microdialysis) were made of Micro-Line Tygon tubing (flexible plastic tubing; 0.020 in inner diameter; 0.060 in outer diameter; Norton Performance Plastics, Norton, OH) and FEP microtubing (CMA Microdialysis; volume, $1.2 \mu \mathrm{l} / 10 \mathrm{~cm}$ ), respectively. A microinfusion pump (Harvard Apparatus 22) was used to perfuse the probes with artificial cerebrospinal fluid $(147 \mathrm{mM} \mathrm{NaCl}$, $1.2 \mathrm{mM} \mathrm{CaCl}_{2}, 0.9 \mathrm{mM} \mathrm{MgCl}_{2}, 4.0 \mathrm{mM} \mathrm{KCl}$ ). Probe recovery was performed by sampling a standard dopamine solution in vitro (Kuczenski et al, 1997; Kuczenski and Segal, 1997). In vitro probe recovery was $8-17 \%$ for dopamine, with a mean of $11.49 \pm 0.8 \%$.

\section{In Vivo Microdialysis Sampling}

Microdialysis sessions were conducted in animals either 1 week after surgery (Experiment 1 ) or $24 \mathrm{~h}$ after the last nicotine self-administration session, which was approximately 4 weeks after surgery (Experiments 2 and $3 a-c$ ). Microdialysis probes were introduced into the NAcc shell via the guide cannula, at least $18 \mathrm{~h}$ (habituation period) before the collection of the dialysis samples, using either brief isoflurane (Experiments 1 and 2; 1-3\%) or methohexital sodium anesthesia (Experiments $3 \mathrm{a}-\mathrm{c} ; 0.2 \mathrm{ml}$ of $50 \mathrm{mg} / \mathrm{ml}$ solution; that is, approximately $25 \mathrm{mg} / \mathrm{kg} ; 500 \mathrm{mg}$ Brevital sodium; JHP Pharmaceuticals, Rochester, MI). In Experiments $3 \mathrm{a}-\mathrm{c}$, the use of methohexital helped with both probe introduction and ensuring catheter patency because the animals received nicotine intravenously during the dialysis session in these experiments. After the introduction of the probes in the NAcc shell, the animals were placed in either Chambers A (Experiments 1, 2, and 3c) or Chambers $B$ (Experiments $3 a$ and $b$ ) for the entire habituation period $(18 \mathrm{~h})$ and subsequent microdialysis sampling. To allow free movement of the animals during the dialysis session, the animals were attached by a head block tether assembly (M115; Instech Laboratories, Plymouth Meeting, PA) to a swivel (375/22PS; Instech Laboratories) and a counter- balanced lever arm. During the habituation period, all animals were provided with food and water, and their microdialysis probes were perfused with artificial cerebrospinal fluid (described above) at a rate of $0.2 \mu \mathrm{l} / \mathrm{min}$. This procedure was followed in all experiments to allow adequate equilibration of the dialysis probes and acclimatize the rats to the dialysis chamber before dialysate sampling.

The rate at which artificial cerebrospinal fluid was perfused through the probes was increased to $1.5 \mu \mathrm{l} / \mathrm{min}$ at least $60 \mathrm{~min}$ before the collection of the baseline dialysate samples. In Experiments 1 and 2, the dialysate was collected every 20 min outside of the dialysis chamber into $200 \mu \mathrm{l}$ conical polyethylene vials (Sun Sri, Rockwood, TN) prefilled with $20 \mu \mathrm{l}$ of $0.2 \mathrm{M}$ sodium citrate in $20 \%$ methanol, $\mathrm{pH}$ 4.0. In Experiments $3 \mathrm{a}-\mathrm{c}$, the dialysate was collected every $10 \mathrm{~min}$ into $200 \mu \mathrm{l}$ conical glass vials (C4012-529L; National Scientific, Rockwood, TN) prefilled with $10 \mu \mathrm{l}$ of $0.2 \mathrm{M}$ sodium citrate in $20 \%$ methanol, $\mathrm{pH}$ 4.0. For the microdialysis sessions, the rats were randomly assigned to saline or LY379268 pretreatment groups, ensuring that rats from each experimental group within an experiment were equally represented in each dialysis session. The saline/LY379268 pretreatment was always experimenteradministered via a subcutaneous injection. All animals were habituated to the subcutaneous injections before the microdialysis sessions. Nicotine administration during the dialysis sessions was determined by the aim of each experiment. Details about the nicotine self-administration sessions (Experiments 2 and $3 \mathrm{a}-\mathrm{c}$ ) and the microdialysis sessions for all experiments are provided in the next subsection.

\section{Experimental Design}

Experiment 1: effects of LY379268 pretreatment and subcutaneous experimenter-administered nicotine on NAcc shell dopamine in nicotine-naïve rats. Nicotinenaïve rats were surgically prepared with an intracranial guide aimed $2 \mathrm{~mm}$ above the NAcc shell. After at least 1 week of recovery from surgery, a microdialysis probe was inserted through the guide cannula under brief isoflurane anesthesia at least $18 \mathrm{~h}$ before the initiation of the dialysis session. The rats were housed in Chambers A (described above) for the habituation period and subsequent dialysate sampling. Initially, three baseline samples were collected during the first hour. Subsequently, rats were randomly assigned to one of five treatment groups, each treated with two subcutaneous injections separated by $20 \mathrm{~min}$ : (i) saline + nicotine $(0.4 \mathrm{mg} / \mathrm{kg})$; (ii) LY379268 (1 mg/kg) + nicotine (0.4 mg/kg); (iii) LY379268 (1 mg/kg) + saline; (iv) LY379268 $(3 \mathrm{mg} / \mathrm{kg})+$ nicotine $(0.4 \mathrm{mg} / \mathrm{kg}) ;$ and $(\mathrm{v}) \mathrm{LY} 379268(3 \mathrm{mg} / \mathrm{kg})$ + saline. Samples were collected every $20 \mathrm{~min}$ for $3 \mathrm{~h}$ after the subcutaneous administration of nicotine.

Experiment 2: effects of LY379268 pretreatment and subcutaneous experimenter-administered nicotine on NAcc shell dopamine in nicotine-experienced rats. As described previously (Liechti et al, 2007), the rats were initially trained to lever press for food (45 mg Noyes food pellets) in Chambers $B$ (these chambers were later used for nicotine self-administration for these animals, but the dialysis 
session was not conducted in these chambers, but rather in Chambers A; see below). The rats then underwent a single surgical session during which an intracranial guide cannula was implanted $2 \mathrm{~mm}$ above the NAcc shell, and an intravenous catheter was inserted into the jugular vein. After at least 1 week of recovery from surgery, the rats were allowed to self-administer nicotine $(0.03 \mathrm{mg} / \mathrm{kg}$ per infusion in $0.1 \mathrm{ml}$ over $1 \mathrm{~s}$ ) under a fixed-ratio 5 , timeout $20 \mathrm{~s}$ (FR5 TO $20 \mathrm{~s}$ ) schedule of reinforcement during $1 \mathrm{~h}$ sessions in Chambers B for 3 weeks ( 5 days per week). The delivery of an infusion was paired with a cue light located above the active lever that was lit simultaneously with the initiation of the nicotine infusion and remained illuminated throughout the 20-s timeout period, during which responding was recorded but not reinforced. Responses on the inactive lever were recorded but had no consequences.

Microdialysis probes were inserted in the NAcc shell through the intracranial guide cannula under brief isoflurane anesthesia at least $18 \mathrm{~h}$ before the initiation of dialysate sampling. In addition, as in Experiment 1, the animals were housed in Chambers A for the habituation period and subsequent dialysate sampling. Chambers A were never associated with nicotine self-administration, and these animals were not exposed to these chambers before the 18-h habituation period and dialysis session. During the dialysis session, the rats were randomly assigned to one of three treatment groups, each treated with two subcutaneous injections separated by $20 \mathrm{~min}$ : (i) saline + nicotine $(0.4 \mathrm{mg} / \mathrm{kg})$; (ii) LY379268 $(1 \mathrm{mg} / \mathrm{kg})+$ nicotine $(0.4 \mathrm{mg} / \mathrm{kg})$; and (iii) LY379268 (1 mg/kg) + saline. Dialysate samples were collected every $20 \mathrm{~min}$ as in Experiment 1.

Experiments $3 a-c$ : effects of LY379268 pretreatment and a single intravenous nicotine infusion (self- or experimenter-administered) on NAcc shell dopamine in nicotine-experienced rats either in the presence or absence of a nicotine-associated context. Food training and the surgical procedures were identical to those used in Experiment 2. After recovery from surgery, the animals were allowed to self-administer nicotine in Chambers B. Rats initially self-administered $0.03 \mathrm{mg} / \mathrm{kg}$ per infusion nicotine in $0.1 \mathrm{ml}$ over $1 \mathrm{~s}$ for 1 week and then $0.06 \mathrm{mg} / \mathrm{kg}$ per infusion in $0.1 \mathrm{ml}$ over $1 \mathrm{~s}$ for 3 weeks ( 5 days per week). This selfadministration training protocol was used because (i) it ensured an appreciable increase in NAcc dopamine after a single self- or experimenter-administered infusion of nicotine and (ii) allowed the administration of the same dose of nicotine per infusion during the dialysis session as during the nicotine self-administration sessions. This selfadministration training protocol was based on previous work in our laboratory, in which the initial training to selfadminister $0.03 \mathrm{mg} / \mathrm{kg}$ per infusion nicotine for 1 week led to the development of tolerance to the initial aversive effects of high nicotine doses and thus allowed subsequent nicotine self-administration of $0.06 \mathrm{mg} / \mathrm{kg}$ per infusion (Watkins et al, 1999). Other self-administration parameters, such as fixed-ratio requirement, timeout duration, and the use of a cue light during the nicotine infusion, were identical to those in Experiment 2. After completion of nicotine selfadministration training, the animals underwent microdialysis. Three experiments (Experiments $3 \mathrm{a}-\mathrm{c}$ ) resulted from the experimental manipulations during the microdialysis session. In Experiment $3 \mathrm{a}$, the animals self-administered a single infusion of nicotine $(0.06 \mathrm{mg} / \mathrm{kg}$ per infusion $)$ in a context associated with nicotine self-administration (Chambers B) during the dialysis session. In Experiment $3 \mathrm{~b}$, the animals received a single experimenter-administered infusion of nicotine $(0.06 \mathrm{mg} / \mathrm{kg}$ per infusion $)$ in a context associated with nicotine self-administration (Chambers B) during the dialysis session. Finally, in Experiment $3 c$, the animals received a single experimenter-administered infusion of nicotine $(0.06 \mathrm{mg} / \mathrm{kg}$ per infusion $)$ during the dialysis session in a context never associated with nicotine self-administration (Chambers A). These three experiments were conducted sequentially because the data from each experiment guided the design of the subsequent experiment to allow an integrated interpretation of the data from all of the experiments.

The procedure described below was followed for the microdialysis sessions in Experiments 3a-c. Microdialysis probes were inserted via the intracranial guide cannulae using intravenous methohexital sodium (Brevital sodium) anesthesia at least $18 \mathrm{~h}$ before the initiation of collecting the dialysis samples. Rats with the microdialysis probes were housed in either Chambers B (Experiments 3a and b; that is, chambers associated with nicotine administration) or Chambers A (Experiment 3c; that is, chambers not associated with nicotine administration) for the habituation period and subsequent dialysate sampling period. During the dialysis session, samples were collected every $10 \mathrm{~min}$. Initially, three baseline samples were collected for the first $30 \mathrm{~min}$. Subsequently, rats were randomly assigned to two treatment groups: (i) saline + nicotine $(0.06 \mathrm{mg} / \mathrm{kg}$ per infusion) and (ii) LY379268 (1 mg/kg) + nicotine $(0.06 \mathrm{mg} / \mathrm{kg}$ per infusion). After the collection of baseline samples, the animals received saline/LY379268 pretreatment. Thirty minutes after the saline/LY379268 pretreatment, the animals received a single nicotine infusion that was either self-administered (Experiment 3a) or experimenteradministered (Experiments $3 \mathrm{~b}$ and c; see details below). After the administration of nicotine, samples were collected every $10 \mathrm{~min}$ for $60 \mathrm{~min}$ (six samples). The first sample collection after nicotine administration was delayed for either $2 \mathrm{~min}$ (Experiments $3 \mathrm{a}$ and $\mathrm{b}$ ) or $8 \mathrm{~min}$ (Experiment $3 \mathrm{c}$ ) to account for the dead volume of the probe. The description below highlights the differences during the dialysis sessions in Experiments $3 \mathrm{a}-\mathrm{c}$.

Experiment 3a: effects of LY379268 pretreatment and a single self-administered intravenous nicotine infusion on NAcc shell dopamine in nicotine-experienced rats in a nicotine-associated context. Thirty minutes after the saline/LY379268 pretreatment, the two levers in Chambers B were introduced (an additional cue associated with nicotine administration in the rats), and the animals had the opportunity to self-administer a single infusion of nicotine by pressing the lever five times. The self-administered nicotine infusion was associated with the illumination of a cue light located above the active lever that remained lit for $20 \mathrm{~s}$ after the completion of the FR5 schedule. This was the same cue light that was previously associated with nicotine self-administration. The nicotine infusion parameters were also identical to those used during the 
nicotine self-administration sessions, with the exception that the levers retracted permanently after the single infusion of nicotine. The time required for the animals to complete the FR5 to obtain the nicotine infusion was recorded.

Experiment 3b: effects of LY379268 pretreatment and a single experimenter-administered intravenous nicotine infusion on NAcc shell dopamine in nicotine-experienced rats in a nicotine-associated context. Thirty minutes after the saline/LY379268 pretreatment, the two levers in Chamber B were introduced, but in this experiment, unlike Experiment 3a, the animals received a single experimenteradministered intravenous infusion of nicotine. The nicotine infusion was associated with the illumination of the cue light located above the active lever that remained lit for $20 \mathrm{~s}$, similar to Experiment $3 \mathrm{a}$, and during the nicotine selfadministration sessions. The two levers in Chambers B retracted after the administration of the nicotine infusion, similar to Experiment 3a.

Experiment 3c: effects of LY379268 pretreatment and a single experimenter-administered intravenous nicotine infusion on NAcc shell dopamine in nicotine-experienced rats in a context never associated with nicotine administration. The animals were housed in Chambers $\mathrm{A}$ as described above. Thirty minutes after the saline/LY379268 pretreatment, the animals received a single experimenteradministered intravenous infusion of nicotine, similar to Experiment $3 \mathrm{~b}$. Chambers A, as described above, did not have levers or cue lights.

\section{Dopamine and Monoamine Metabolite Assay}

Samples were assayed for dopamine, 3,4-dihydroxyphenylacetic acid, homovanillic acid, and 5-hydroxyindole acetic acid using reverse-phase high-performance liquid chromatography with electrochemical detection as described previously (Kuczenski et al, 1995).

\section{Histology}

At the end of the experiments, the rats were anesthetized with sodium pentobarbital and decapitated. The brains were removed and fixed in $10 \%$ formalin. The brains were then sliced $(60-\mu \mathrm{m}$-thick coronal sections) on a cryostat to determine the location of the probes.

\section{Statistical Analyses}

Dopamine and metabolite levels are expressed as a percentage of baseline levels (the average of the three samples that preceded the drug treatments) and were analyzed by repeated-measures analysis of variance (ANOVA), with Treatment as the between-subjects factor and Time as the within-subjects factor. Statistically significant main or interaction effects were followed by the NeumanKeuls post hoc test. In Experiment 3a, an unpaired $t$-test was used to analyze the latency to self-administer nicotine in saline- and LY379268-pretreated animals. Cumulative nicotine intake and the number of nicotine infusions $24 \mathrm{~h}$ before the microdialysis session were compared using unpaired t-tests for groups pretreated with LY379268 and saline separately in each of the experiments. Only data from rats with accurate probe placements were included in the analyses.

\section{RESULTS}

Table 1 shows the history of nicotine exposure, cumulative nicotine intake in $\mathrm{mg} / \mathrm{kg}$ (total number of nicotine infusions over all self-administration sessions $\times$ dose of nicotine per infusion), and number of nicotine infusions $24 \mathrm{~h}$ before the dialysis session between saline- and LY379268-pretreated groups. Unpaired $t$-tests showed no significant differences in cumulative nicotine intake over the entire self-administration training period between saline- and LY379268pretreated rats in each experiment. Furthermore, unpaired $t$-tests indicated no significant differences in the number of nicotine infusions self-administered $24 \mathrm{~h}$ before the dialysis session between the saline- and LY379268-pretreated rats in each experiment; the observed differences are within the variability usually observed in nicotine self-administration studies. Comparisons of cumulative nicotine intake and the number of nicotine infusions $24 \mathrm{~h}$ before the dialysis session between the saline- and LY379268-pretreated groups were conducted only within each experiment and not across experiments. The effects of LY379268/saline on nicotine-stimulated NAcc shell dopamine responses were also compared only within each experiment and not across experiments. Finally, no significant differences in metabolite levels were observed after experimenter- or self-administered nicotine in either saline- or LY379268pretreated animals in all experiments (Table 2). Figure 1 shows the active membranes of the probes in the animals used in the data analyses.

Experiment 1: LY379268 Pretreatment did not Block the Increases in NAcc Shell Dopamine after ExperimenterAdministered Subcutaneous Injection of Nicotine in Nicotine-Naive Rats

No significant differences were observed in mean baseline NAcc shell dopamine levels between the saline + nicotine $(28.44 \pm$ $0.54 \mathrm{fmol} / 30 \mu \mathrm{l})$, LY379268 + nicotine $(25.66 \pm 1.84 \mathrm{fmol} / 30 \mu \mathrm{l})$, and LY379268 + saline $(18.24 \pm 0.96 \mathrm{fmol} / 30 \mu \mathrm{l})$ groups. An ANOVA of the percentage data after saline/LY379268 treatment revealed significant main effects of Treatment $\left(\mathrm{F}_{4,28}=9.70\right.$, $p<0.001)$ and Time $\left(\mathrm{F}_{12,336}=4.83, p<0.001\right)$ and a significant Treatment $\times$ Time interaction $\left(\mathrm{F}_{48,336}=3.32, p<0.001\right)$. The Newman-Keuls post hoc test indicated a significant increase in nicotine-stimulated NAcc shell dopamine responses in salinepretreated animals at the $20-40 \mathrm{~min}(p<0.001), 40-60 \mathrm{~min}$ $(p<0.01), 80-100 \mathrm{~min}(p<0.05)$, and $120-140 \mathrm{~min}(p<0.05)$ time-points compared with their respective pretreatment baseline levels (Figure 2a). Similarly, post hoc tests indicated a significant increase in nicotine-stimulated NAcc shell dopamine responses in animals pretreated with LY379268 $(1 \mathrm{mg} / \mathrm{kg})$ at the 40-60 $\mathrm{min}(p<0.05)$ and $60-80 \mathrm{~min}(p<0.05)$ time-points compared with their respective pretreatment baseline levels (Figure 2a). In addition, significant increases in nicotinestimulated NAcc shell dopamine responses were found in the animals pretreated with LY379268 $(3 \mathrm{mg} / \mathrm{kg})$ at the $20-40 \mathrm{~min}$ 
Table I Nicotine Intake in all Groups in all Experiments

\begin{tabular}{|c|c|c|c|c|c|c|}
\hline Experiment & $\begin{array}{l}\text { History of nicotine } \\
\text { self-administration }\end{array}$ & Dialysis context & $\begin{array}{l}\text { Dose and mode } \\
\text { of nicotine delivery } \\
\text { during the dialysis } \\
\text { session }\end{array}$ & Pretreatment & $\begin{array}{c}\text { Cumulative } \\
\text { self-administered } \\
\text { nicotine }(\mathrm{mg} / \mathrm{kg}) \text { over } \\
3 \text { weeks of nicotine } \\
\text { self-administration } \\
\text { training (mean } \pm \text { SEM) }\end{array}$ & $\begin{array}{c}\text { Number of } \\
\text { nicotine infusions/h } \\
\text { (24 h before dialysis) } \\
\text { (mean } \pm \text { SEM) }\end{array}$ \\
\hline । & None & Neutral & $\begin{array}{l}\text { Single experimenter- } \\
\text { administered subcutaneous } \\
\text { injection }(0.4 \mathrm{mg} / \mathrm{kg})\end{array}$ & $\begin{array}{l}\text { LY379268 } \\
\text { Saline }\end{array}$ & $\begin{array}{l}\text { None } \\
\text { None }\end{array}$ & $\begin{array}{l}\text { None } \\
\text { None }\end{array}$ \\
\hline 2 & $\begin{array}{l}0.03 \mathrm{mg} / \mathrm{kg} \text { per infusion } \\
(3 \text { weeks) }\end{array}$ & $\begin{array}{l}\text { Never associated } \\
\text { with nicotine } \\
\text { self-administration }\end{array}$ & $\begin{array}{l}\text { Single experimenter- } \\
\text { administered subcutaneous } \\
\text { injection }(0.4 \mathrm{mg} / \mathrm{kg})\end{array}$ & $\begin{array}{l}\text { LY379268 } \\
\text { Saline }\end{array}$ & $\begin{array}{l}5.32 \pm 1.20 \\
5.50 \pm 0.66\end{array}$ & $\begin{array}{l}9.20 \pm 0.60 \\
9.40 \pm 1.90\end{array}$ \\
\hline $3 a$ & $\begin{array}{l}0.03 \mathrm{mg} / \mathrm{kg} \text { per infusion } \\
(\mathrm{I} \text { week) }+0.06 \mathrm{mg} / \mathrm{kg} \\
\text { per infusion ( } 3 \text { weeks) }\end{array}$ & $\begin{array}{l}\text { Associated with } \\
\text { nicotine } \\
\text { self-administration }\end{array}$ & $\begin{array}{l}\text { Single self-administered } \\
\text { intravenous nicotine } \\
\text { infusion }(0.06 \mathrm{mg} / \mathrm{kg})\end{array}$ & $\begin{array}{l}\text { LY379268 } \\
\text { Saline }\end{array}$ & $\begin{array}{l}9.92 \pm 1.06 \\
7.58 \pm 0.37\end{array}$ & $\begin{array}{r}8.0 \pm 1.29 \\
6.37 \pm 0.92\end{array}$ \\
\hline $3 b$ & $\begin{array}{l}0.03 \mathrm{mg} / \mathrm{kg} \text { per infusion } \\
(\mathrm{I} \text { week)+0.06 mg/kg } \\
\text { per infusion ( } 3 \text { weeks) }\end{array}$ & $\begin{array}{l}\text { Associated with } \\
\text { nicotine self- } \\
\text { administration }\end{array}$ & $\begin{array}{l}\text { Single experimenter- } \\
\text { administered intravenous } \\
\text { nicotine infusion } \\
(0.06 \mathrm{mg} / \mathrm{kg})\end{array}$ & $\begin{array}{l}\text { LY379268 } \\
\text { Saline }\end{array}$ & $\begin{array}{l}12.06 \pm 1.5 \\
9.78 \pm 0.60\end{array}$ & $\begin{array}{r}11.08 \pm 1.25 \\
8.60 \pm 0.74\end{array}$ \\
\hline $3 c$ & $\begin{array}{l}0.03 \mathrm{mg} / \mathrm{kg} \text { per infusion } \\
(\mathrm{I} \text { week)+0.06 mg/kg } \\
\text { per infusion ( } 3 \text { weeks) }\end{array}$ & $\begin{array}{l}\text { Never associated } \\
\text { with nicotine } \\
\text { self-administration }\end{array}$ & $\begin{array}{l}\text { Single experimenter- } \\
\text { administered intravenous } \\
\text { nicotine infusion } \\
(0.06 \mathrm{mg} / \mathrm{kg})\end{array}$ & $\begin{array}{l}\text { LY379268 } \\
\text { Saline }\end{array}$ & $\begin{array}{l}7.32 \pm 0.64 \\
9.67 \pm 1.30\end{array}$ & $\begin{array}{r}8.75 \pm 2.03 \\
12.14 \pm 1.76\end{array}$ \\
\hline
\end{tabular}

a Values reported only for I mg/kg dose of LY379268.

$(p<0.05), \quad 40-60 \mathrm{~min}(p<0.01), 60-80 \mathrm{~min} \quad(p<0.01), 80-$ $100 \mathrm{~min}(p<0.05)$, and $100-120 \mathrm{~min}(p<0.05)$ time-points compared with their respective pretreatment baseline levels (Figure 2a). Post hoc tests indicated no significant difference in NAcc shell dopamine responses after experimenter-administered nicotine between saline- and LY379268- ( 1 and $3 \mathrm{mg} / \mathrm{kg}$ ) pretreated animals at any time-point. Significant decreases in NAcc shell dopamine levels were found in animals pretreated with LY379268 $(3 \mathrm{mg} / \mathrm{kg})$ alone at the $0-20 \mathrm{~min}(p<0.05)$ and $40-60$ min $(p<0.05)$ time-points compared with their respective baseline levels (Figure 2a). Post hoc tests indicated no significant difference in NAcc shell dopamine levels between animals pretreated with LY379268 (1 mg/kg) and LY379268 (3 mg/kg) at any time-point.

\section{Experiment 2: LY379268 Pretreatment did not Block the Increases in NAcc Shell Dopamine after an Experimenter-Administered Subcutaneous Injection of Nicotine in Nicotine-Experienced Rats in a Context Never Associated with Nicotine Self-Administration}

No significant differences were observed in mean baseline NAcc shell dopamine levels between the saline + nicotine $(22.51 \pm$ $0.98 \mathrm{fmol} / 30 \mu \mathrm{l}), \mathrm{LY} 379268+$ nicotine $(17.56 \pm 0.96 \mathrm{fmol} / 30 \mu \mathrm{l})$, and LY379268 + saline $(23.28 \pm 1.96 \mathrm{fmol} / 30 \mu \mathrm{l})$ groups. An ANOVA revealed significant main effects of Treatment $\left(\mathrm{F}_{2,19}=5.718, p<0.01\right)$ and Time $\left(\mathrm{F}_{12,228}=5.401, p<0.001\right)$ and a significant Treatment $\times$ Time interaction $\left(\mathrm{F}_{24,228}=\right.$
$3.48, p<0.001)$. The Newman-Keuls post hoc tests indicated significant increases in nicotine-stimulated NAcc shell dopamine responses in saline-pretreated animals at the 20-40 min $(p<0.05), \quad 40-60 \mathrm{~min} \quad(p<0.05), \quad 80-100 \mathrm{~min}$ $(p<0.05)$, and $100-120 \mathrm{~min}(p<0.05)$ time-points compared with their respective pretreatment baseline levels (Figure $2 b$ ). Similarly, post hoc tests indicated significant increases in nicotine-stimulated NAcc shell dopamine responses in animals pretreated with LY379268 $(1 \mathrm{mg} / \mathrm{kg})$ at the $20-$ 40 min $(p<0.001), 40-60 \min (p<0.05), 60-80 \min (p<0.01)$, and $80-100 \mathrm{~min}(p<0.01)$ time-points compared with their respective pretreatment baseline levels (Figure 2b). No significant differences in NAcc dopamine responses were found after experimenter-administered nicotine between the salineand LY379268-pretreated animals at any time-point. In the animals treated with LY379268 $(1 \mathrm{mg} / \mathrm{kg})$ alone, no significant change in NAcc shell dopamine levels was found compared with their respective baseline levels.

\section{Experiment 3a: LY379268 Pretreatment Blocked the Increases in NAcc Shell Dopamine after a Single Self-Administered Intravenous Infusion of Nicotine in Nicotine-Experienced Rats in a Context Associated with Nicotine Self-Administration}

No significant difference in mean baseline NAcc shell dopamine levels was observed between the LY379268$(8.27 \pm 1.96 \mathrm{fmol} / 15 \mu \mathrm{l})$ and saline- $(8.68 \pm 1.70 \mathrm{fmol} / 15 \mu \mathrm{l})$ 
Table 2 DA, DOPAC, HVA, and 5-HIAA Levels in all Experimental Groups ${ }^{\mathrm{a}}$

\begin{tabular}{|c|c|c|c|c|c|c|c|c|}
\hline \multirow[t]{2}{*}{$\begin{array}{l}\text { Experi- } \\
\text { ment }\end{array}$} & \multirow[t]{2}{*}{$\begin{array}{l}\text { History of } \\
\text { nicotine self- } \\
\text { administration }\end{array}$} & \multirow[t]{2}{*}{$\begin{array}{l}\text { Dialysis } \\
\text { context }\end{array}$} & \multirow[t]{2}{*}{$\begin{array}{l}\text { Dose and mode of } \\
\text { nicotine delivery during } \\
\text { the dialysis session }\end{array}$} & \multirow[t]{2}{*}{ Pretreatment } & \multicolumn{4}{|c|}{$\begin{array}{c}\text { Mean } \pm \text { SEM after nicotine } \\
\text { administration (values expressed } \\
\text { as percentage of baseline) }\end{array}$} \\
\hline & & & & & DA (\%) & DOPAC (\%) & HVA (\%) & 5-HIAA (\%) \\
\hline $1^{b}$ & None & Neutral & $\begin{array}{l}\text { Single experimenter- } \\
\text { administered subcutaneous } \\
\text { injection }(0.4 \mathrm{mg} / \mathrm{kg})\end{array}$ & $\begin{array}{l}\text { LY379268 } \\
\text { Saline }^{c}\end{array}$ & $\begin{array}{l}145 \pm 10.7 \\
155 \pm 18.5\end{array}$ & $\begin{array}{l}108 \pm 2.13 \\
96.2 \pm 4.6\end{array}$ & $\begin{array}{l}113 \pm 4.2 \\
115 \pm 7.8\end{array}$ & $\begin{array}{l}109 \pm 4.7 \\
104 \pm 0.7\end{array}$ \\
\hline $2^{b}$ & $\begin{array}{l}0.03 \text { mg/kg per } \\
\text { infusion ( } 3 \text { weeks) }\end{array}$ & $\begin{array}{l}\text { Never associated } \\
\text { with nicotine } \\
\text { self-administration }\end{array}$ & $\begin{array}{l}\text { Single experimenter- } \\
\text { administered subcutaneous } \\
\text { injection }(0.4 \mathrm{mg} / \mathrm{kg})\end{array}$ & $\begin{array}{l}\text { LY379268 } \\
\text { Saline }\end{array}$ & $\begin{array}{l}190 \pm 18.9 \\
175 \pm 21.3\end{array}$ & $\begin{array}{l}125 \pm 7.0 \\
102 \pm 6.7\end{array}$ & $\begin{array}{l}123 \pm 15.3 \\
118 \pm 9.3\end{array}$ & $\begin{array}{l}117 \pm 3.79 \\
102 \pm 6.54\end{array}$ \\
\hline $3 a^{d}$ & $\begin{array}{l}0.03 \mathrm{mg} / \mathrm{kg} \text { per infusion } \\
(\mathrm{I} \text { week) }+0.06 \mathrm{mg} / \mathrm{kg} \\
\text { per infusion ( } 3 \text { weeks) }\end{array}$ & $\begin{array}{l}\text { Associated with } \\
\text { nicotine self- } \\
\text { administration }\end{array}$ & $\begin{array}{l}\text { Single self-administered } \\
\text { intravenous nicotine infusion } \\
(0.06 \mathrm{mg} / \mathrm{kg})\end{array}$ & $\begin{array}{l}\text { LY379268 } \\
\text { Saline }\end{array}$ & $\begin{array}{l}101 \pm 11.7 \\
254 \pm 14.1\end{array}$ & $\begin{array}{r}|18.85 \pm 7 .| \\
|4| \pm 2 \mid .2\end{array}$ & $\begin{array}{l}107 \pm 7.1 \\
135 \pm 17.8\end{array}$ & $\begin{array}{l}132.7 \pm 16.9 \\
1 \mid 3.7 \pm 5.4\end{array}$ \\
\hline $3 b^{d}$ & $\begin{array}{l}0.03 \mathrm{mg} / \mathrm{kg} \text { per infusion } \\
(\mathrm{I} \text { week) }+0.06 \mathrm{mg} / \mathrm{kg} \\
\text { per infusion ( } 3 \text { weeks) }\end{array}$ & $\begin{array}{l}\text { Associated with } \\
\text { nicotine self- } \\
\text { administration }\end{array}$ & $\begin{array}{l}\text { Single experimenter- } \\
\text { administered intravenous } \\
\text { nicotine infusion }(0.06 \mathrm{mg} / \mathrm{kg})\end{array}$ & $\begin{array}{l}\text { LY379268 } \\
\text { Saline }\end{array}$ & $\begin{array}{r}101 \pm 11.7 \\
207.4 \pm 14.1\end{array}$ & $\begin{array}{c}103 \pm 9.2 \\
88.90 \pm 20.6\end{array}$ & $\begin{array}{r}110 \pm 11.2 \\
93.4 \pm 44.0\end{array}$ & $\begin{array}{l}102 \pm 8.9 \\
103 \pm 17.4\end{array}$ \\
\hline $3 c^{d}$ & $\begin{array}{l}0.03 \mathrm{mg} / \mathrm{kg} \text { per infusion } \\
(\mathrm{I} \text { week) }+0.06 \mathrm{mg} / \mathrm{kg} \\
\text { per infusion ( } 3 \text { weeks) }\end{array}$ & $\begin{array}{l}\text { Never associated } \\
\text { with nicotine } \\
\text { self-administration }\end{array}$ & $\begin{array}{l}\text { Single experimenter- } \\
\text { administered intravenous } \\
\text { nicotine infusion }(0.06 \mathrm{mg} / \mathrm{kg})\end{array}$ & $\begin{array}{l}\text { LY379268 } \\
\text { Saline }\end{array}$ & $\begin{array}{r}217.6 \pm 34.0 \\
203 \pm 33.1\end{array}$ & $\begin{array}{l}111.2 \pm 19.3 \\
107.5 \pm 13.3\end{array}$ & $\begin{array}{r}103.7 \pm 22.8 \\
96.3 \pm 15.1\end{array}$ & $\begin{array}{l}106.7 \pm 9.9 \\
103.2 \pm 15.2\end{array}$ \\
\hline
\end{tabular}

Abbreviations: DA, dopamine; DOPAC, 3,4-dihydroxyphenylacetic acid; HVA, homovanillic acid; 5-HIAA, 5-hydroxyindole acetic acid.

a $V$ alues expressed as percentage of baseline.

balues reflect DA, DOPAC, HVA, and 5-HIAA levels 40 min after subcutaneous nicotine injection.

'Values reflect DA, DOPAC, HVA, and 5-HIAA levels 10 min after a single intravenous infusion of nicotine.

'Values reported only for I mg/kg dose of LY379268.

pretreated groups. An ANOVA revealed significant main effects of Treatment $\left(\mathrm{F}_{1,13}=25.2, p<0.001\right)$ and Time $\left(\mathrm{F}_{11,143}=7.31, p<0.001\right)$ and a significant Treatment $\times$ Time interaction $\left(\mathrm{F}_{11,143}=6.68, p<0.001\right)$. The Newman-Keuls post hoc test indicated significant increases in NAcc dopamine responses after a single self-administered infusion of nicotine in saline-pretreated animals at the $0-10 \mathrm{~min}(p<0.001), 10-20 \mathrm{~min}(p<0.05)$, and $30-40 \mathrm{~min}$ $(p<0.05)$ time-points compared with their respective baseline levels. LY379268 pretreatment blocked the increases in NAcc shell dopamine levels induced by self-administration of a single nicotine infusion, revealed by the Newman-Keuls post hoc test that indicated significant differences in NAcc dopamine responses between the saline- and LY379268pretreated animals at the $0-10 \mathrm{~min}(p<0.001), 10-20 \mathrm{~min}$ $(p<0.001), 20-30 \mathrm{~min}(p<0.001), 30-40 \mathrm{~min}(p<0.05)$, and 50-60 min $(p<0.001)$ time-points after nicotine selfadministration (Figure 3). Animals pretreated with LY379268 exhibited a significant increase in the latency (16.12 $\pm 4 \mathrm{~min})$ to complete the FR5 schedule to receive the nicotine infusion compared with saline-pretreated rats $(5.33 \pm 1.3 \mathrm{~min}$; $\left.t_{1,12}=2.37, p<0.01\right)$. Because sampling was initiated after the animals had received an infusion of nicotine, the difference in nicotine-induced dopamine responses between the salineand LY379268-pretreated groups was not likely attributable to this difference in latency between the two groups.
Experiment 3b: LY379268 Pretreatment Blocked the Increases in NAcc Shell Dopamine after a Single Experimenter-Administered Infusion of Nicotine in Nicotine-Experienced Rats in a Context Associated with Nicotine Self-Administration

No significant difference in mean baseline NAcc shell dopamine levels was observed between the LY379268$(7.83 \pm 0.98 \mathrm{fmol} / 15 \mu \mathrm{l})$ and saline- $(5.37 \pm 0.77 \mathrm{fmol} / 15 \mu \mathrm{l})$ pretreated groups. An ANOVA revealed significant main effects of Treatment $\left(\mathrm{F}_{1,7}=15.26, p<0.01\right)$ and Time $\left(\mathrm{F}_{11,77}=1.93, p<0.05\right)$ and a significant Treatment $\times$ Time interaction $\left(\mathrm{F}_{11,77}=1.98, p<0.05\right)$. The Newman-Keuls post hoc test indicated a significant increase in NAcc dopamine levels in saline-pretreated animals after a single experimenter-administered infusion of nicotine at the $0-10 \mathrm{~min}$ $(p<0.01)$ time-point compared with their respective baseline levels. Pretreatment with LY379268 (1 mg/kg) blocked the increase in NAcc shell dopamine levels induced by a single experimenter-administered infusion of nicotine in a context associated with nicotine self-administration in nicotine-experienced animals, revealed by post hoc tests that indicated significant differences in NAcc dopamine responses between the saline- and LY379268pretreated animals at the $0-10 \mathrm{~min}(p<0.01)$ time-point immediately after nicotine administration (Figure 4 ). Both 

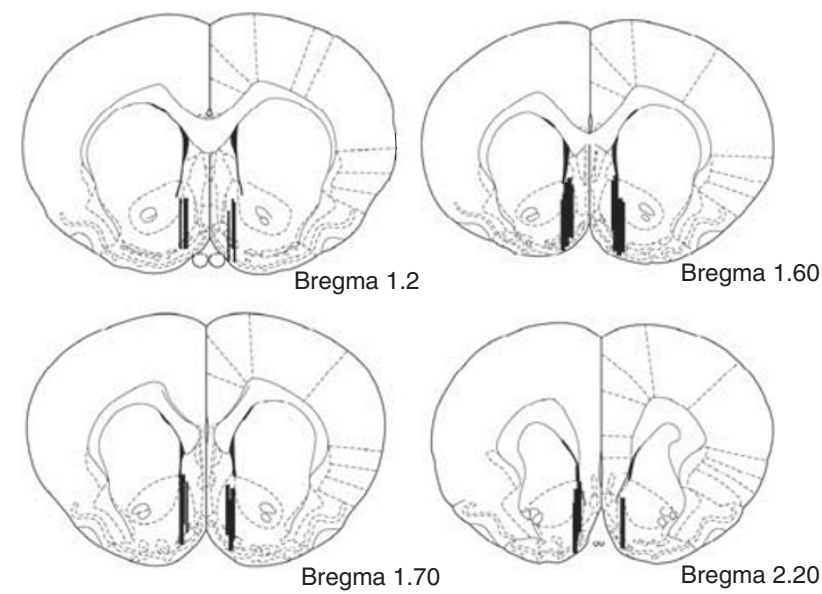

Figure I Diagrams of coronal sections from the rat brain atlas (Paxinos and Watson, 1998). Marked lines represent histologically confirmed locations of microdialysis probe tips (active membrane) in the nucleus accumbens (NAcc) shell from animals that were included in the statistical analyses for all experiments. Numbers next to the coronal section indicate the distance from bregma in millimeters.

the active and inactive levers were extended into the chambers just before the passive infusion and retracted immediately after the nicotine infusion. None of the animals pressed either the active or inactive lever either before or during the lever extension despite their previous experience with nicotine self-administration.

\section{Experiment 3c: LY379268 Pretreatment did not Block the Increases in NAcc Shell Dopamine after a Single Experimenter-Administered Infusion of Intravenous Nicotine in Nicotine-Experienced Rats in a Context Never Associated with Nicotine Self-Administration}

No significant difference in mean baseline NAcc shell dopamine levels was observed between the LY379268$(4.48 \pm 0.44 \mathrm{fmol} / 15 \mu \mathrm{l})$ and saline- $(3.58 \pm 0.78 \mathrm{fmol} / 15 \mu \mathrm{l})$ pretreated groups. An ANOVA revealed a significant main effect of Time $\left(\mathrm{F}_{11,99}=2.29, p<0.05\right)$ but no main effect of Treatment $\left(\mathrm{F}_{1,9}=0.01, p>0.05\right)$ and no Treatment $\times$ Time interaction $\left(\mathrm{F}_{11,99}=0.65, p>0.05\right)$. This pattern of results and subsequent post hoc tests (see below) indicated that pretreatment with LY379268 did not block the increased NAcc shell dopamine levels after a single passive infusion of nicotine in a context never associated with nicotine self-administration in nicotine-experienced animals (Figure 5). Specifically, the Newman-Keuls post hoc test revealed a significant increase in NAcc dopamine levels in both saline- and LY379268-pretreated animals after a single experimenter-administered infusion of nicotine in nicotine-experienced animals in the absence of a nicotine-associated context at the $0-10 \mathrm{~min}$ time-point compared with their respective baseline levels $(p<0.05)$. Importantly, no statistically significant differences in nicotine-induced dopamine responses were found between the saline- and LY379268-treated groups at any time-point.
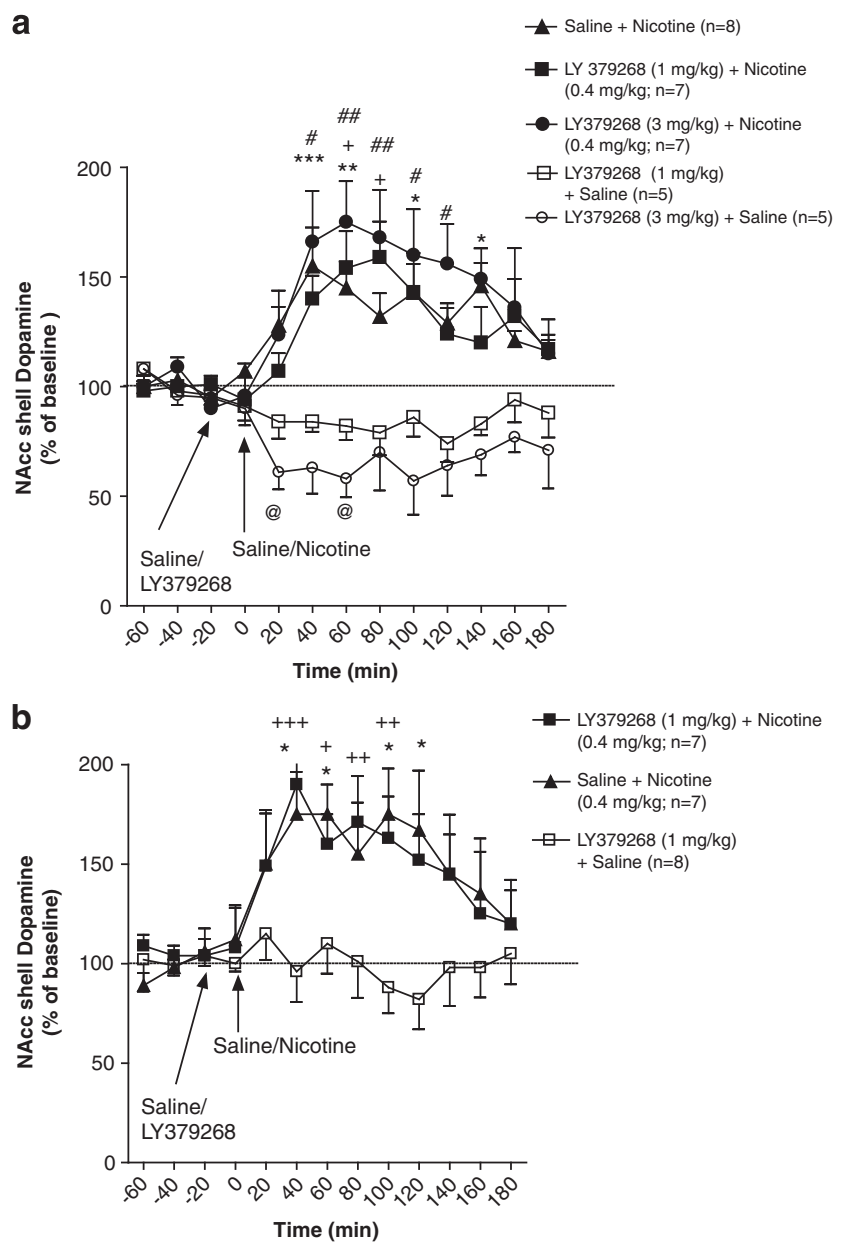

Figure 2 Effect of LY379268 ([-]-2-oxa-4-aminobicyclo [3.1.0] hexane4,6-dicarboxylate; I and $3 \mathrm{mg} / \mathrm{kg}$ ) on nucleus accumbens (NAcc) shell dopamine after experimenter-administered subcutaneous nicotine $(0.4 \mathrm{mg} /$ $\mathrm{kg}$ ) administration in (a; Experiment I) nicotine-naïve and (b; Experiment 2) nicotine-experienced rats in a context never associated with nicotine selfadministration. Dopamine levels (mean \pm standard error of mean [SEM]) are expressed as a percentage of baseline values. (a) $* p<0.05$, ** $p<0.01$, **** $p<0.00$ I, saline + nicotine compared with respective baseline levels; ${ }^{+} p<0.05, L Y 379268(\mathrm{I} \mathrm{mg} / \mathrm{kg})+$ nicotine compared with respective baseline levels; ${ }_{p} p<0.05,{ }^{\# \#} p<0.01, \quad L Y 379268$ (3 mg/kg) + nicotine compared with respective baseline levels; and $@_{p}<0.05$, LY379268 $(3 \mathrm{mg} / \mathrm{kg})+$ saline compared with respective baseline levels. (b) $* p<0.05$, saline + nicotine compared with respective baseline levels; and ${ }^{+} p<0.05$, ${ }^{++} p<0.0 \mathrm{I},{ }^{+++} p<0.00 \mathrm{I}, \quad$ LY379268 $(\mathrm{I} \mathrm{mg} / \mathrm{kg})+$ nicotine compared with respective baseline levels.

\section{DISCUSSION}

In saline-pretreated rats, nicotine increased NAcc shell dopamine regardless of whether the dialysis session occurred in a context associated with or never associated with nicotine self-administration. Pretreatment with the mGlu2/3 receptor agonist LY379268 completely blocked the nicotine-induced increases in NAcc shell dopamine in nicotine-experienced rats only in the presence of a context associated with nicotine self-administration (Figures 3 and 4). In contrast, pretreatment with LY379268 did not block the nicotine-induced increases in NAcc shell dopamine in nicotine-experienced rats tested in a context not associated with nicotine self-administration or nicotine-naïve rats 


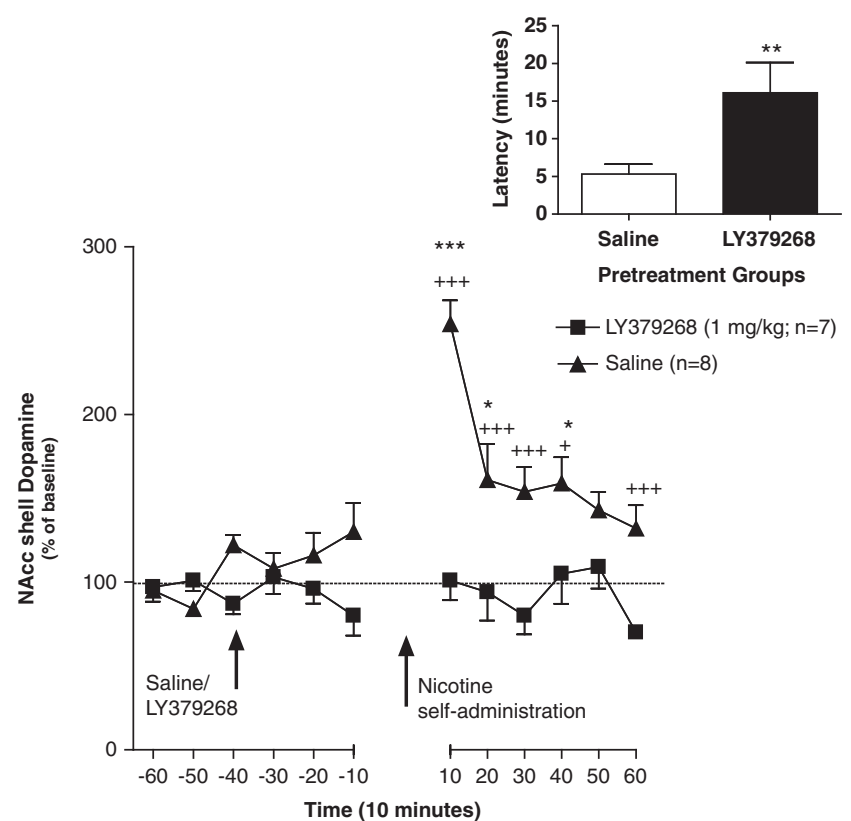

Figure 3 Effect of LY379268 ([-]-2-oxa-4-aminobicyclo [3. I.0] hexane4,6-dicarboxylate; I $\mathrm{mg} / \mathrm{kg}$ ) on nucleus accumbens (NAcc) shell dopamine after self-administration of a single intravenous infusion of nicotine $(0.06 \mathrm{mg} / \mathrm{kg}$ per infusion over $\mathrm{Is}$ ) in nicotine-experienced animals in a context associated with nicotine self-administration (Experiment 3a). Dopamine levels (mean \pm standard error of mean [SEM]) are expressed as a percentage of baseline values. $* p<0.05$, **** $p<0.001$, salinepretreated compared with their own baseline levels; and ${ }^{+} p<0.05$,

${ }^{++} p<0.01,{ }^{++} p<0.001$, saline-pretreated compared with LY379268pretreated animals. (Inset) Latency (mean \pm SEM) in minutes to selfadminister nicotine in saline- and LY379268-pretreated animals. $* * * 0.0$ I, LY379268-pretreated group compared with saline-pretreated group. The time period between -10 and 10 depicts the time taken by the animals to self-administer nicotine and the dead volume of the probe (no samples were collected during that period). The time taken to self-administer nicotine varied among LY379268- and saline-pretreated animals. On the basis of the dead volume of the tubing, sample collection was initiated $2 \mathrm{~min}$ after nicotine self-administration in all animals.

tested in a neutral context. Thus, the present data suggest that mGlu2/3 receptors are involved in regulating the combined effects of nicotine and contextual/discrete stimuli on NAcc shell dopamine in rats.

Contextual and discrete stimuli are two distinct entities that can have differential behavioral effects, possibly mediated by different subdivisions (core $v s$ shell) of the NAcc (Chaudhri et al, 2010; Bossert et al, 2007; Fuchs et al, 2004, 2008). This study focused on providing a wellsupported conclusion about the conditions that lead to the reversal of nicotine-induced increases in NAcc dopamine levels after the initial surprising lack of reversal of nicotineinduced dopamine increases by LY379268 in Experiment 1. Differentiating between the effects of the context and discrete environmental stimuli on the observed effects was not feasible in this study because of the nature of the data that were gradually emerging with each subsequent experiment. Each experiment built on the surprising and revealing results of the previous experiments, with the necessity of maintaining identical experimental conditions with the exception of varying one variable at a time in each subsequent experiment. Nevertheless, the generated results

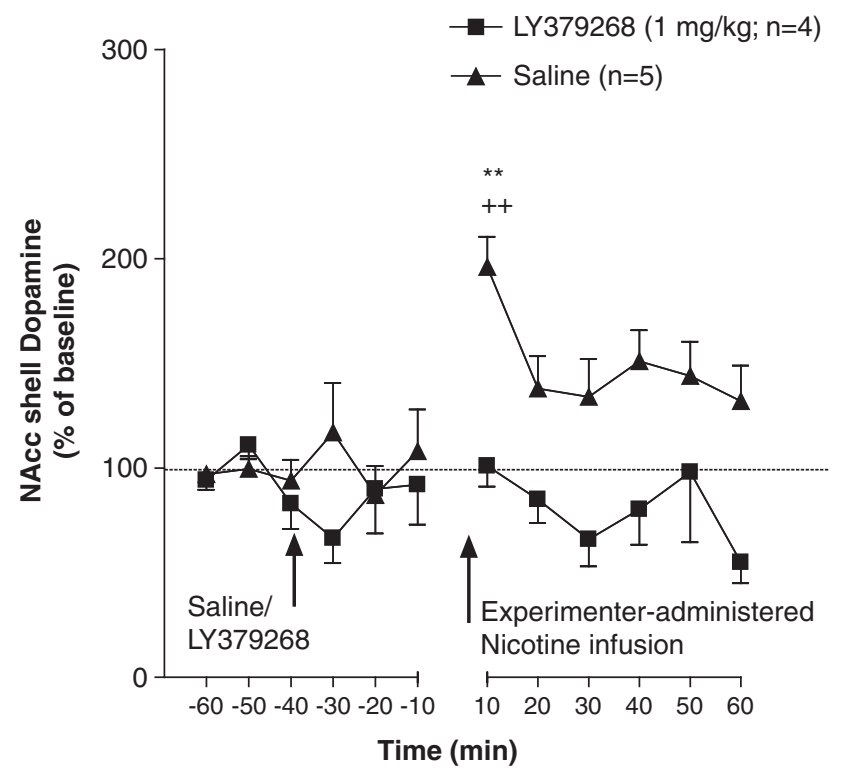

Figure 4 Effect of LY379268 ([-]-2-oxa-4-aminobicyclo [3.1.0] hexane-4,6-dicarboxylate; I mg/kg) on nucleus accumbens (NAcc) shell dopamine after a single experimenter-administered intravenous infusion of nicotine $(0.06 \mathrm{mg} / \mathrm{kg}$ per infusion over $/ \mathrm{s})$ in nicotineexperienced animals in a context associated with nicotine self-administration (Experiment $3 b$ ). Dopamine levels (mean \pm standard error of mean [SEM]) are expressed as a percentage of baseline values. $* * * 00.0$ I, salinepretreated compared with their own baseline levels; ${ }^{++} p<0.01$, salinepretreated compared with LY379268-pretreated animals. The time period between -10 and 10 depicts the dead volume of the probe, which was 2 min.

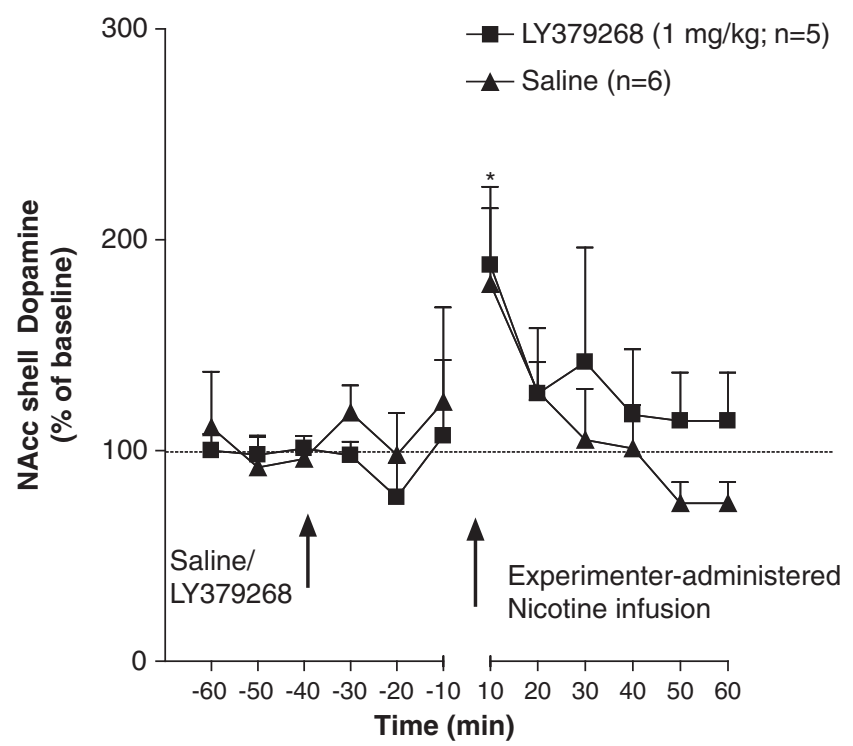

Figure 5 Effect of LY379268 ([-]-2-oxa-4-aminobicyclo [3. I.0] hexane4,6-dicarboxylate; I mg/kg) on nucleus accumbens (NAcc) shell dopamine after a single experimenter-administered intravenous infusion of nicotine $(0.06 \mathrm{mg} / \mathrm{kg}$ per infusion over I s) in nicotine-experienced animals in a context never associated with nicotine self-administration (Experiment 3c). Dopamine levels (mean \pm standard error of mean [SEM]) are expressed as a percentage of baseline values. ${ }^{*} p<0.05$, saline- and LY379268pretreated compared with their respective baseline levels. The time period between -10 and 10 depicts the dead volume of the probe, which was 8 min. 
provide clear evidence about the neurochemical mechanisms that contribute to the effects of agonist actions at mGlu2/3 receptors on nicotine self-administration and drug-seeking behavior. Both of these behaviors involve responses to context + stimuli previously associated with nicotine availability and self-administration. These findings are highly relevant to situations encountered by human beings, in which both contexts and stimuli associated with smoking behavior are encountered simultaneously, similar to the present experiments.

Nicotine-naïve animals had the highest basal dopamine levels (Experiment 1). In Experiment 2, animals selfadministered nicotine $0.03 \mathrm{mg} / \mathrm{kg}$ per infusion for 3 weeks and had slightly lower basal dopamine levels compared with the nicotine-naïve animals. The highest exposure to nicotine was in animals from Experiments $3 \mathrm{a}-\mathrm{c}$ who selfadministered nicotine $0.03 \mathrm{mg} / \mathrm{kg}$ per infusion for 1 week and $0.06 \mathrm{mg} / \mathrm{kg}$ per infusion for 3 weeks. These animals also had the lowest basal dopamine levels compared with all other groups. The lower basal dopamine levels in nicotineexperienced rats (Experiments 2 and $3 \mathrm{a}-\mathrm{c}$ ) are consistent with previously published findings (Rahman et al, 2004). Using the no-net-flux technique, Rahman et al (2004) demonstrated that nicotine self-administration experience, similar to that used in our study, resulted in lower basal dopamine levels in nicotine-experienced animals compared with nicotine-naïve animals. These data suggest that nicotine exposure dose-dependently results in decreased NAcc shell dopamine levels. However, drawing firm conclusions about the basal levels of dopamine across experimental groups with different self-administration experiences based solely on the data presented here is difficult because the no-net-flux technique was not used in this study. The differences in basal dopamine levels between nicotine-naïve and -experienced rats, although interesting, are peripheral to the questions this study sought to answer. Because of our awareness of these differences in basal levels, quantitative comparisons about effect sizes among groups from different experiments groups were not made. Comparisons were only made between groups within the same experiment that exhibited no significant differences in basal dopamine levels. These comparisons addressed the experimental question of whether LY379268 could reverse or at least attenuate the effects of nicotine on NAcc dopamine.

The NAcc dopamine response (Experiment 1) after subcutaneous nicotine administration $(0.4 \mathrm{mg} / \mathrm{kg})$ in nicotine-naïve animals was similar to that reported previously (Bednar et al, 2004; Kosowski et al, 2004; Schilstrom et al, 1998). Similarly, increases in NAcc shell dopamine after subcutaneous nicotine administration $(0.4 \mathrm{mg} / \mathrm{kg})$ in nicotine-experienced animals (Experiment 2) were also consistent with previously published findings (Bednar et al, 2004; Benwell and Balfour, 1992; Cadoni and Di Chiara, 2000). Both a self- and experimenter-administered single infusion of nicotine $(0.06 \mathrm{mg} / \mathrm{kg}$ over $1 \mathrm{~s})$ significantly increased NAcc shell dopamine in animals with a history of chronic nicotine self-administration regardless of the context used during the dialysis session (ie, context associated with nicotine self-administration $v s$ context never associated with nicotine self-administration). However, a previous study reported no change in NAcc dopamine levels after a very slow (over $60 \mathrm{~s}$ ) intravenous infusion of the same nicotine dose $(0.06 \mathrm{mg} / \mathrm{kg})$ in animals with chronic nicotine self-administration experience (Rahman et al, 2004). The discrepancy between the findings of Rahman et al (2004) and this study could be attributable to methodological differences between the two studies, particularly the rate at which nicotine was infused during the dialysis session (60 vs $1 \mathrm{~s}$ in our study) and location of the probes (core and shell $v s$ shell in our study).

LY379268 (1 mg/kg) alone did not alter NAcc shell dopamine levels in nicotine-naïve or -experienced rats (Figure 2a and b). The higher LY379268 dose $(3 \mathrm{mg} / \mathrm{kg})$, when tested on its own in nicotine-naïve rats, decreased NAcc shell dopamine levels at some time-points postadministration compared with baseline dopamine levels (Figure 2a). This LY379268-induced dose-dependent decrease in basal NAcc shell dopamine levels in nicotine-naïve rats is consistent with previously published results (Greenslade and Mitchell, 2004; Hu et al, 1999; Kim et al, 2005; Xi et al, 2010a,b). Taken together, these findings reflect the fact that activation of $\mathrm{mGlu} 2 / 3$ receptors on presynaptic glutamate terminals decreases glutamate release, which in turn results in lower activation of dopamine neurons in areas such as the VTA and consequently decreases in dopamine release in terminal areas such as the NAcc. Because LY379268 administration $(3 \mathrm{mg} / \mathrm{kg}$ ) blocked both nicotine and food self-administration (Liechti et al, 2007), indicating a lack of reinforcer selectivity at this dose and impairment of locomotor activity at higher doses $(6-10 \mathrm{mg} /$ $\mathrm{kg}$; Imre, 2007), we did not assess the effects of $3 \mathrm{mg} / \mathrm{kg}$ or higher doses of LY379268 beyond Experiment 1. Importantly, LY379268 (1 mg/kg) selectively attenuated nicotine, but not food, self-administration and had no effect on locomotor activity (Imre, 2007; Liechti et al, 2007); therefore, this dose was used in all subsequent experiments.

In the presence of a nicotine-associated context, pretreatment with LY379268 (1 mg/kg) completely blocked the increase in NAcc shell dopamine induced by a single intravenous infusion of nicotine, independent of whether the nicotine was self- or experimenter-administered (Figures 3 and 4). In contrast, in the absence of a nicotine-associated context, pretreatment with LY379268 did not attenuate intravenous nicotine-induced increases in NAcc shell dopamine (Figure 5).

In addition, LY379268-pretreated rats, which did not exhibit increases in NAcc shell dopamine after selfadministration of nicotine in the presence of a nicotineassociated context, exhibited a significant delay in initiating nicotine seeking and nicotine self-administration compared with saline-pretreated rats tested under otherwise identical experimental conditions (see Figure 3, inset). Nicotineassociated contexts and cues can significantly impact behavioral responses to nicotine. Indeed, animals show enhanced nicotine self-administration in the presence of contexts and cues associated with nicotine (Caggiula et al, 2001, 2002; Chaudhri et al, 2006). Previous work from our laboratory has shown that LY379268-pretreated animals exhibit decreased nicotine self-administration in the presence of nicotine-associated contexts and cues (Liechti et al, 2007). In addition, the same study by Liechti and coworkers and work from other laboratories reported that LY379268 attenuates context/cue-induced motivated behavior, such as cue-induced reinstatement of nicotine-, 
heroin-, and food-seeking behavior (Baptista et al, 2004; Bossert et al, 2005, 2006; Liechti et al, 2007). Therefore, the increase in latency to self-administer nicotine after treatment with LY379268 likely reflects a decrease in motivation to seek and self-administer nicotine and is consistent with the results of the aforementioned studies. Altogether, the present neurochemical and behavioral data (ie, increased latency to self-administer nicotine in LY379268-pretreated rats) suggest that a possible mechanism that contributes to the attenuation of nicotine self-administration by LY379268 (Liechti et al, 2007) may be inhibition of nicotine-induced dopamine release in the NAcc shell.

It must be emphasized, however, that nicotine increases the release of several neurotransmitters, including glutamate, by activating excitatory nicotinic heteroreceptors located on presynaptic terminals of neurons containing these neurotransmitters (Balfour, 2009; Fu et al, 2000; Reid et al, 2000; Wonnacott, 1997). In addition, drug-associated context and cues increase glutamatergic neurotransmission (Hotsenpiller et al, 2001; Bell et al, 2000). Therefore, blockade of nicotine-induced dopamine release in the NAcc shell may not be the only mechanism by which LY379268 increases the latency to self-administer nicotine and attenuates nicotine intake. As described in the Introduction, LY379268 decreases glutamate release by activating inhibitory presynaptic mGlu2/3 receptors (Cartmell and Schoepp, 2000; Xi et al, 2002a), and blockade of glutamatergic neurotransmission also attenuates the reinforcing effects of nicotine (Kenny et al, 2009, 2003; Liechti and Markou, 2007; Palmatier et al, 2008; Paterson and Markou, 2005; Paterson et al, 2003). Therefore, mGlu2/3-mediated attenuation of glutamatergic neurotransmission is likely to be another mechanism contributing to LY379268-induced increases in the latency to self-administer nicotine (this study) and attenuation of the reinforcing effects of nicotine (Liechti et al, 2007).

These data are consistent with a significant body of literature that demonstrated an attenuation of both basal and psychostimulant-induced increases in mesolimbic dopaminergic neurotransmission upon either direct or indirect activation of mGlu2/3 receptors (Greenslade and Mitchell, 2004; Hu et al, 1999; Kim et al, 2005; Uslaner et al, 2009; Xi et al, 2010a, b). Importantly, these results advance data from the aforementioned studies because they emphasize a role for nicotine-associated contexts and cues in the effects of LY379268 on nicotine-induced increases in the NAcc dopamine response.

Although the mechanism of action by which the nicotineassociated context influences the effects of LY379268 is not known, our findings can be explained on the basis of alterations in mGlu2/3 receptor function, some of which are reported in the literature. Animals tested in the presence of a nicotine-associated context were also exposed to this context during the habituation period $(18 \mathrm{~h})$. Drug-associated contexts and cues enhance glutamatergic transmission (Hotsenpiller et al, 2001; Bell et al, 2000). Because mGlu2/3 receptors negatively regulate glutamatergic transmission, we postulate that mGlu2/3 receptor function is rapidly upregulated in the presence of a nicotine-associated context to counteract the context-induced enhancement of glutamatergic transmission. Recent studies reported that upregulation in mGlu2/3 receptor function may be respon- sible for the increased pharmacological efficacy of the mGlu2/3 agonist LY379268, resulting in a leftward shift of the dose-response curve (Aujla et al, 2008; Hao et al, 2010). Thus, based on the results from these studies and our findings, we hypothesize that the nicotine-associated context resulted in rapid upregulation of $\mathrm{mGlu} 2 / 3$ receptors, which in turn enhanced the pharmacological efficacy of LY379268, resulting in the attenuation of nicotine-induced increases in NAcc shell dopamine only in the presence of a nicotine-associated context.

By contrast, in the absence of a nicotine-associated context, repeated nicotine self-administration experience and subsequent early withdrawal ( $\sim 24 \mathrm{~h}$ after nicotine selfadministration) results in mGlu2/3 receptor function downregulation, reflected by decreased coupling of mGlu2/3 receptors to $G$ proteins (Liechti et al, 2007). This downregulation possibly occurs as a counteradaptation to the hypothesized development of a hypoglutamatergic state during early withdrawal after a period of chronic nicotine self-administration (Kenny and Markou, 2004). Such downregulation in mGlu2/3 receptor function would result in a rightward shift of the dose-response curve for agonists that act at the mGlu2/3 receptor. Consistent with this hypothesis, a rightward shift of the dose-response curve for the mGlu2/3 agonist $2 R, 4 R$-4-aminopyrrolidine-2,4-dicarboxylate was seen after downregulation in mGlu2/3 receptor function in animals with chronic cocaine self-administration experience (Xi et al, 2002b). Thus, we hypothesize that in the absence of a nicotine-associated context, mGlu2/3 receptor function was downregulated in animals with chronic nicotine selfadministration experience, resulting in a rightward shift of the dose-response curve, consequently resulting in the lack of efficacy of LY379268 on the nicotine-induced increases in the NAcc dopamine response.

The above hypothesis, however, does not explain why LY379268 is not effective in nicotine-naïve animals. In nicotine-naïve animals, mGlu2/3 receptors may not have a role in regulating nicotine-induced increases in NAcc shell dopamine (Fu et al, 2000), or very high doses may be required to attenuate nicotine-induced increases in NAcc shell dopamine. Another possible mechanism for the lack of effects of LY379268 in nicotine-naïve and -experienced animals tested in a context not associated with nicotine selfadministration could be novelty-induced stress induced by exposure to a new environment (Chambers A) in these animals. However, novelty-induced stress is unlikely to be a factor because animals were housed in the dialysis chambers for at least $18 \mathrm{~h}$ before dialysate sample collection.

The precise concentration of LY379268 achieved in the synapse after subcutaneous LY379268 $(1 \mathrm{mg} / \mathrm{kg})$ administration is not known. LY379268, although relatively specific for $\mathrm{mGlu} 2 / 3$ receptors $\left(\mathrm{EC}_{50}=3-6 \mu \mathrm{M}\right)$, can have weak agonist activity at mGlu4 $\left(\mathrm{EC}_{50}=20 \mu \mathrm{M}\right)$, mGlu6 $\left(\mathrm{EC}_{50}=\right.$ $400 \mu \mathrm{M})$, and mGlu8 $\left(\mathrm{EC}_{50}=2 \mu \mathrm{M}\right)$ receptors. Thus, actions at these receptors may potentially contribute to the effects of LY379268 at high doses. However, the present results are not likely to be attributable to the action of LY379268 on receptors other than mGlu2/3 receptors because of the low dose $(1 \mathrm{mg} / \mathrm{kg})$ of LY379268 used in this study compared doses $(3-10 \mathrm{mg} / \mathrm{kg})$ frequently used in the literature to observe reliable behavioral or neurochemical effects (Cartmell et al, 2000a-c; Liechti et al, 2007; Riegel et al, 2003). 
Because LY379268 acts on both mGlu2 and mGlu3 receptors, determining which group of receptors played a more important role in attenuating the combined effects of nicotine and a nicotine-associated context seen in this study is difficult. Presynaptically located mGlu2 receptors are expressed at higher densities than mGlu3 receptors in several limbic nuclei, including the NAcc in the rat $(\mathrm{Gu}$ et al, 2008). Furthermore, mGlu2 receptor knockout mice exhibited an increase in cocaine-induced place preference compared with wild-type mice, suggesting that activation of mGlu2 receptors has a more important role than mGlu3 receptors in inhibiting the effects of drug-associated contexts and cues (Morishima et al, 2005). In addition, LY379268 blocked amphetamine-induced hyperactivity in wild-type and mGlu3 knockout mice, but not in mGlu2 knockout mice, indicating that mGlu2 receptors are required for the ability of LY379268 to attenuate the behavioral effects of psychostimulants (Woolley et al, 2008). Nevertheless, because knockout mice likely undergo compensatory changes, and LY379268 acts on both mGlu2 and mGlu3 receptors, conclusively determining which of the two mGlu receptors (mGlu2 or mGlu3) have a more important role in blocking the combined effects of nicotine and a nicotine-associated context on NAcc shell dopamine in these studies is difficult.

In summary, pretreatment with the mGlu2/3 receptor agonist LY379268 attenuated the nicotine-induced increases in NAcc shell dopamine only in the presence of a nicotineassociated context. These data therefore suggest that activation of mGlu2/3 receptors has a greater impact on the synergistic effects of nicotine and nicotine-associated contexts than on the pharmacological actions of nicotine alone on nicotine-induced increases in NAcc shell dopamine. These results advance our understanding of the role $\mathrm{mGlu} 2 / 3$ receptors in nicotine-induced neurochemical and behavioral responses. In conclusion, these findings have high clinical relevance because human tobacco smokers are more likely to relapse to tobacco smoking after a period of abstinence in an environment associated with smoking. Therefore, by blocking the combined effects of nicotine and nicotine-associated contexts, mGlu2/3 receptor agonists may be effective in preventing relapse to tobacco smoking in abstinent smokers.

\section{ACKNOWLEDGEMENTS}

This work was supported by National Institutes of Health Grants DA11946 to AM and MH080001 to RK. MSD was supported by fellowship 19FT-0045 from the TobaccoRelated Disease Research Program of the State of California. MEL was supported by a fellowship from the Swiss National Science Foundation (SNF-PBZHB-108501, SSMBS 1246) and F Hofmann-La Roche Ltd (Basel, Switzerland). We thank Mr Michael Arends for editorial assistance.

\section{DISCLOSURE}

Dr Markou has received contract research support from Intracellular Therapeutics Inc., Lundbeck Research USA Inc., Bristol-Myers Squibb Co., F Hoffman-La Roche Ind., Pfizer, and Astra-Zeneca and honoraria/consulting fees from Abbott GmbH and Company, AstraZeneca, and Pfizer during the past 3 years. Dr Markou has a patent application on the use of metabotropic glutamate compounds for the treatment of nicotine dependence. The other authors report no financial conflict of interests.

\section{REFERENCES}

Aujla H, Martin-Fardon R, Weiss F (2008). Rats with extended access to cocaine exhibit increased stress reactivity and sensitivity to the anxiolytic-like effects of the mGluR $2 / 3$ agonist LY379268 during abstinence. Neuropsychopharmacology 33: $1818-1826$.

Balfour DJ (2009). Nicotine psychopharmacology: the neuronal pathways mediating the behavioral and addictive properties of nicotine. In: Henningfield JE, London ED, Pogun S (eds). Nicotine Psychopharmacology (series title: Handbook of Experimental Pharmacology, Vol 192). Springer, Berlin. pp 209-233.

Baptista MA, Martin-Fardon R, Weiss F (2004). Preferential effects of the metabotropic glutamate $2 / 3$ receptor agonist LY379268 on conditioned reinstatement versus primary reinforcement: comparison between cocaine and a potent conventional reinforcer. J Neurosci 24: 4723-4727.

Bednar I, Friberg L, Nordberg A (2004). Modulation of dopamine release by the nicotinic agonist epibatidine in the frontal cortex and the nucleus accumbens of naive and chronic nicotine treated rats. Neurochem Int 45: 1049-1055.

Bell K, Duffy P, Kalivas PW (2000). Context-specific enhancement of glutamate transmission by cocaine. Neuropsychopharmaco$\log y$ 23: 335-344.

Benwell ME, Balfour DJ (1992). The effects of acute and repeated nicotine treatment on nucleus accumbens dopamine and locomotor activity. Br J Pharmacol 105: 849-856.

Bossert JM, Busch RF, Gray SM (2005). The novel mGluR2/3 agonist LY379268 attenuates cue-induced reinstatement of heroin seeking. NeuroReport 16: 1013-1016.

Bossert JM, Gray SM, Lu L, Shaham Y (2006). Activation of group II metabotropic glutamate receptors in the nucleus accumbens shell attenuates context-induced relapse to heroin seeking. Neuropsychopharmacology 31: 2197-2209.

Bossert JM, Poles GC, Wihbey K A, Koya E, Shaham Y (2007). Differential effects of blockade of dopamine $D_{1}$-family receptors in nucleus accumbens core or shell on reinstatement of heroin seeking induced by contextual and discrete cues. J Neurosci 27: 12655-12663.

Cadoni C, Di Chiara G (2000). Differential changes in accumbens shell and core dopamine in behavioral sensitization to nicotine. Eur J Pharmacol 387: R23-R25.

Caggiula AR, Donny EC, White AR, Chaudhri N, Booth S, Gharib MA et al (2001). Cue dependency of nicotine self-administration and smoking. Pharmacol Biochem Behavior 70: 515-530.

Caggiula AR, Donny EC, White AR, Chaudhri N, Booth S, Gharib MA et al (2002). Environmental stimuli promote the acquisition of nicotine self-administration in rats. Psychopharmacology 163: 230-237.

Cartmell J, Monn JA, Schoepp DD (2000a). Tolerance to the motor impairment, but not to the reversal of PCP-induced motor activities by oral administration of the mGlu2/3 receptor agonist, LY379268. Naunyn-Schmiedebergs Arch Pharmacol 361: 39-46.

Cartmell J, Perry KW, Salhoff CR, Monn JA, Schoepp DD (2000b). The potent, selective mGlu2/3 receptor agonist LY379268 increases extracellular levels of dopamine, 3,4-dihydroxyphenylacetic acid, homovanillic acid, and 5-hydroxyindole-3-acetic acid in the medial prefrontal cortex of the freely moving rat. J Neurochem 75: 1147-1154. 
Cartmell J, Schoepp DD (2000). Regulation of neurotransmitter release by metabotropic glutamate receptors. J Neurochem 75: 889-907.

Cartmell J, Salhoff CR, Perry KW, Monn JA, Schoepp DD (2000c). Dopamine and 5-HT turnover are increased by the mGlu2/3 receptor agonist LY379268 in rat medial prefrontal cortex, nucleus accumbens and striatum. Brain Res 887: 378-384.

Chaudhri N, Caggiula AR, Donny EC, Palmatier MI, Liu X, Sved AF (2006). Complex interactions between nicotine and nonpharmacological stimuli reveal multiple roles for nicotine in reinforcement. Psychopharmacology 184: 353-366.

Chaudhri N, Sahuque LL, Schairer WW, Janak PH (2010). Separable roles of the nucleus accumbens core and shell in context- and cue-induced alcohol-seeking. Neuropsychopharmacology 35: 783-791.

Di Chiara G (2000). Role of dopamine in the behavioural actions of nicotine related to addiction. Eur J Pharmacol 393: 295-314.

Fu Y, Matta SG, Gao W, Brower VG, Sharp BM (2000). Systemic nicotine stimulates dopamine release in nucleus accumbens: re-evaluation of the role of $N$-methyl-D-aspartate receptors in the ventral tegmental area. J Pharmacol Exp Ther 294: 458-465.

Fuchs RA, Evans KA, Parker MC, See RE (2004). Differential involvement of the core and shell subregions of the nucleus accumbens in conditioned cue-induced reinstatement of cocaine seeking in rats. Psychopharmacology 176: 459-465.

Fuchs RA, Ramirez DR, Bell GH (2008). Nucleus accumbens shell and core involvement in drug context-induced reinstatement of cocaine seeking in rats. Psychopharmacology 200: 545-556.

Gu G, Lorrain DS, Wei H, Cole RL, Zhang X, Daggett LP et al (2008). Distribution of metabotropic glutamate 2 and 3 receptors in the rat forebrain: implication in emotional responses and central disinhibition. Brain Res 1197: 47-62.

Goldberg SR, Henningfield JE (1988). Reinforcing effects of nicotine in humans and experimental animals responding under intermittent schedules of i.v. drug injection. Pharmacol Biochem Behav 30: 227-234.

Greenslade RG, Mitchell SN (2004). Selective action of (-)-2-oxa4-aminobicyclo[3.1.0]hexane-4,6-dicarboxylate (LY379268), a group II metabotropic glutamate receptor agonist, on basal and phencyclidine-induced dopamine release in the nucleus accumbens shell. Neuropharmacology 47: 1-8.

Hao Y, Martin-Fardon R, Weiss F (2010). Behavioral and functional evidence of metabotropic glutamate receptor $2 / 3$ and metabotropic glutamate receptor 5 dysregulation in cocaineescalated rats: factor in the transition to dependence. Biol Psychiatry 68: 240-248.

Hemby SE, Co C, Koves TR, Smith JE, Dworkin SI (1997). Differences in extracellular dopamine concentrations in the nucleus accumbens during response-dependent and responseindependent cocaine administration in the rat. Psychopharmacology 133: 7-16.

Hotsenpiller G, Giorgetti M, Wolf ME (2001). Alterations in behaviour and glutamate transmission following presentation of stimuli previously associated with cocaine exposure. Eur J Neurosci 14: 1843-1855.

Hu G, Duffy P, Swanson C, Ghasemzadeh MB, Kalivas PW (1999). The regulation of dopamine transmission by metabotropic glutamate receptors. J Pharmacol Exp Ther 289: 412-416.

Imre G (2007). The preclinical properties of a novel group II metabotropic glutamate receptor agonist LY379268. CNS Drug Rev 13: 444-464.

Karasawa J, Yoshimizu T, Chaki S (2006). A metabotropic glutamate 2/3 receptor antagonist, MGS0039, increases extracellular dopamine levels in the nucleus accumbens shell. Neurosci Lett 393: 127-130.

Kenny PJ, Chartoff E, Roberto M, Carlezon Jr WA, Markou A (2009). NMDA receptors regulate nicotine-enhanced brain reward function and intravenous nicotine self-administration: role of the ventral tegmental area and central nucleus of the amygdala. Neuropsychopharmacology 34: 266-281.

Kenny PJ, Markou A (2004). The ups and downs of addiction: role of metabotropic glutamate receptors. Trends Pharmacol Sci 25: 265-272.

Kenny PJ, Paterson NE, Boutrel B, Semenova S, Harrison AA, Gasparini F et al (2003). Metabotropic glutamate 5 receptor antagonist MPEP decreased nicotine and cocaine self-administration but not nicotine and cocaine-induced facilitation of brain reward function in rats. Ann N Y Acad Sci 1003: 415-418.

Kim JH, Austin JD, Tanabe L, Creekmore E, Vezina P (2005). Activation of group II mGlu receptors blocks the enhanced drug taking induced by previous exposure to amphetamine. Eur J Neurosci 21: 295-300 [erratum: 25, 908].

Koob GF, Volkow ND (2010). Neurocircuitry of addiction. Neuropsychopharmacology 35: 217-238 [erratum: 35, 1051].

Kosowski AR, Cebers G, Cebere A, Swanhagen AC, Liljequist S (2004). Nicotine-induced dopamine release in the nucleus accumbens is inhibited by the novel AMPA antagonist ZK200775 and the NMDA antagonist CGP39551. Psychopharmacology 175: 114-123.

Kuczenski R, Segal D (1989). Concomitant characterization of behavioral and striatal neurotransmitter response to amphetamine using in vivo microdialysis. J Neurosci 9: 2051-2065.

Kuczenski R, Segal DS (1997). An escalating dose/multiple highdose binge pattern of amphetamine administration results in differential changes in the extracellular dopamine response profiles in caudate-putamen and nucleus accumbens. J Neurosci 17: 4441-4447.

Kuczenski R, Segal DS, Cho AK, Melega W (1995). Hippocampus norepinephrine, caudate dopamine and serotonin, and behavioral responses to the stereoisomers of amphetamine and methamphetamine. J Neurosci 15: 1308-1317.

Kuczenski R, Segal DS, Todd PK (1997). Behavioral sensitization and extracellular dopamine responses to amphetamine after various treatments. Psychopharmacology 134: 221-229.

Laviolette SR, van der Kooy D (2004). The neurobiology of nicotine addiction: bridging the gap from molecules to behaviour. Nat Rev Neurosci 5: 55-65.

Lecca D, Cacciapaglia F, Valentini V, Acquas E, Di Chiara G (2007). Differential neurochemical and behavioral adaptation to cocaine after response contingent and noncontingent exposure in the rat. Psychopharmacology 191: 653-667.

Liechti ME, Lhuillier L, Kaupmann K, Markou A (2007). Metabotropic glutamate $2 / 3$ receptors in the ventral tegmental area and the nucleus accumbens shell are involved in behaviors relating to nicotine dependence. J Neurosci 27: 9077-9085.

Liechti ME, Markou A (2007). Interactive effects of the mGlu5 receptor antagonist MPEP and the mGlu2/3 receptor antagonist LY341495 on nicotine self-administration and reward deficits associated with nicotine withdrawal in rats. Eur J Pharmacol 554: 164-174.

Mansvelder HD, McGehee DS (2002). Cellular and synaptic mechanisms of nicotine addiction. J Neurobiol 53: 606-617.

Manzoni O, Michel JM, Bockaert J (1997). Metabotropic glutamate receptors in the rat nucleus accumbens. Eur J Neurosci 9: $1514-1523$

Monn JA, Valli MJ, Massey SM, Hansen MM, Kress TJ, Wepsiec JP et al (1999). Synthesis, pharmacological characterization, and molecular modeling of heterobicyclic amino acids related to $(+)$ 2-aminobicyclo[3.1.0] hexane-2,6-dicarboxylic acid (LY354740): identification of two new potent, selective, and systemically active agonists for group II metabotropic glutamate receptors. J Med Chem 42: 1027-1040.

Morishima Y, Miyakawa T, Furuyashiki T, Tanaka Y, Mizuma H, Nakanishi S (2005). Enhanced cocaine responsiveness and impaired motor coordination in metabotropic glutamate receptor subtype 2 knockout mice. Proc Natl Acad Sci U S A 102: $4170-4175$. 
Overton PG, Clark D (1997). Burst firing in midbrain dopaminergic neurons. Brain Res Brain Res Rev 25: 312-334.

Palmatier MI, Liu X, Donny EC, Caggiula AR, Sved AF (2008). Metabotropic glutamate 5 receptor (mGluR5) antagonists decrease nicotine seeking, but do not affect the reinforcement enhancing effects of nicotine. Neuropsychopharmacology 33: 2139-2147.

Paterson NE, Markou A (2005). The metabotropic glutamate receptor 5 antagonist MPEP decreased break points for nicotine, cocaine and food in rats. Psychopharmacology 179: 255-261.

Paterson NE, Semenova S, Gasparini F, Markou A (2003). The mGluR5 antagonist MPEP decreased nicotine self-administration in rats and mice. Psychopharmacology 167: 257-264.

Paxinos G, Watson C (1998). The Rat Brain in Stereotaxic Coordinates, 4th edn. Academic Press: San Diego, CA.

Picciotto MR, Corrigall WA (2002). Neuronal systems underlying behaviors related to nicotine addiction: neural circuits and molecular genetics. J Neurosci 22: 3338-3341.

Rahman S, Zhang J, Engleman EA, Corrigall WA (2004). Neuroadaptive changes in the mesoaccumbens dopamine system after chronic nicotine self-administration: a microdialysis study. Neuroscience 129: 415-424.

Reid MS, Fox L, Ho LB, Berger SP (2000). Nicotine stimulation of extracellular glutamate levels in the nucleus accumbens: neuropharmacological characterization. Synapse 35: 129-136.

Riegel AC, Ali SF, French ED (2003). Toluene-induced locomotor activity is blocked 6-hydroxydopamine lesions of the nucleus accumbens and the mGluR2/3 agonist LY379268. Neuropsychopharmacology 28: 1440-1447.

Schilstrom B, Nomikos GG, Nisell M, Hertel P, Svensson TH (1998). $N$-methyl-D-aspartate receptor antagonism in the ventral tegmental area diminishes the systemic nicotine-induced dopamine release in the nucleus accumbens. Neuroscience 82: 781-789.

Stolerman IP, Jarvis MJ (1995). The scientific case that nicotine is addictive. Psychopharmacology 117: 2-10; discussion 14-20.

Sziraki I, Sershen H, Hashim A, Lajtha A (2002). Receptors in the ventral tegmental area mediating nicotine-induced dopamine release in the nucleus accumbens. Neurochem Res 27: 253-261.

Taber MT, Das S, Fibiger HC (1995). Cortical regulation of subcortical dopamine release: mediation via the ventral tegmental area. J Neurochem 65: 1407-1410.
Taber MT, Fibiger HC (1995). Electrical stimulation of the prefrontal cortex increases dopamine release in the nucleus accumbens of the rat: modulation by metabotropic glutamate receptors. J Neurosci 15: 3896-3904.

Testa CM, Friberg IK, Weiss SW, Standaert DG (1998). Immunohistochemical localization of metabotropic glutamate receptors mGluR1a and mGluR2/3 in the rat basal ganglia. J Comp Neurol 390: 5-19.

Uslaner JM, Smith SM, Huszar SL, Pachmerhiwala R, Hinchliffe RM, Vardigan JD et al (2009). Combined administration of an mGlu2/3 receptor agonist and a $5-\mathrm{HT}_{2 \mathrm{~A}}$ receptor antagonist markedly attenuate the psychomotor-activating and neurochemical effects of psychostimulants. Psychopharmacology 206: 641-651.

Watkins SS, Epping-Jordan MP, Koob GF, Markou A (1999). Blockade of nicotine self-administration with nicotinic antagonists in rats. Pharmacol Biochem Behav 62: 743-751.

Watkins SS, Koob GF, Markou A (2000). Neural mechanisms underlying nicotine addiction: acute positive reinforcement and withdrawal. Nicotine Tob Res 2: 19-37.

Wise RA (1987). The role of reward pathways in the development of drug dependence. Pharmacol Ther 35: 227-263.

Wonnacott S (1997). Presynaptic nicotinic ACh receptors. Trends Neurosci 20: 92-98.

Woolley ML, Pemberton DJ, Bate S, Corti C, Jones DN (2008). The mGlu2 but not the mGlu3 receptor mediates the actions of the mGluR2/3 agonist, LY379268, in mouse models predictive of antipsychotic activity. Psychopharmacology 196: 431-440.

Xi ZX, Baker DA, Shen H, Carson DS, Kalivas PW (2002a). Group II metabotropic glutamate receptors modulate extracellular glutamate in the nucleus accumbens. J Pharmacol Exp Ther 300: $162-171$.

Xi ZX, Kiyatkin M, Li X, Peng XQ, Wiggins A, Spiller $\mathrm{K}$ et al (2010a). $\mathrm{N}$-acetylaspartylglutamate (NAAG) inhibits intravenous cocaine self-administration and cocaine-enhanced brain-stimulation reward in rats. Neuropharmacology 58: 304-313.

Xi ZX, Ramamoorthy S, Baker DA, Shen H, Samuvel DJ, Kalivas PW (2002b). Modulation of group II metabotropic glutamate receptor signaling by chronic cocaine. J Pharmacol Exp Ther 303: 608-615.

Xi ZX, Li X, Peng XQ, Li J, Chun L, Gardner EL et al (2010b). Inhibition of NAALADase by 2-PMPA attenuates cocaineinduced relapse in rats: a NAAG-mGluR2/3-mediated mechanism. J Neurochem 112: 564-576. 